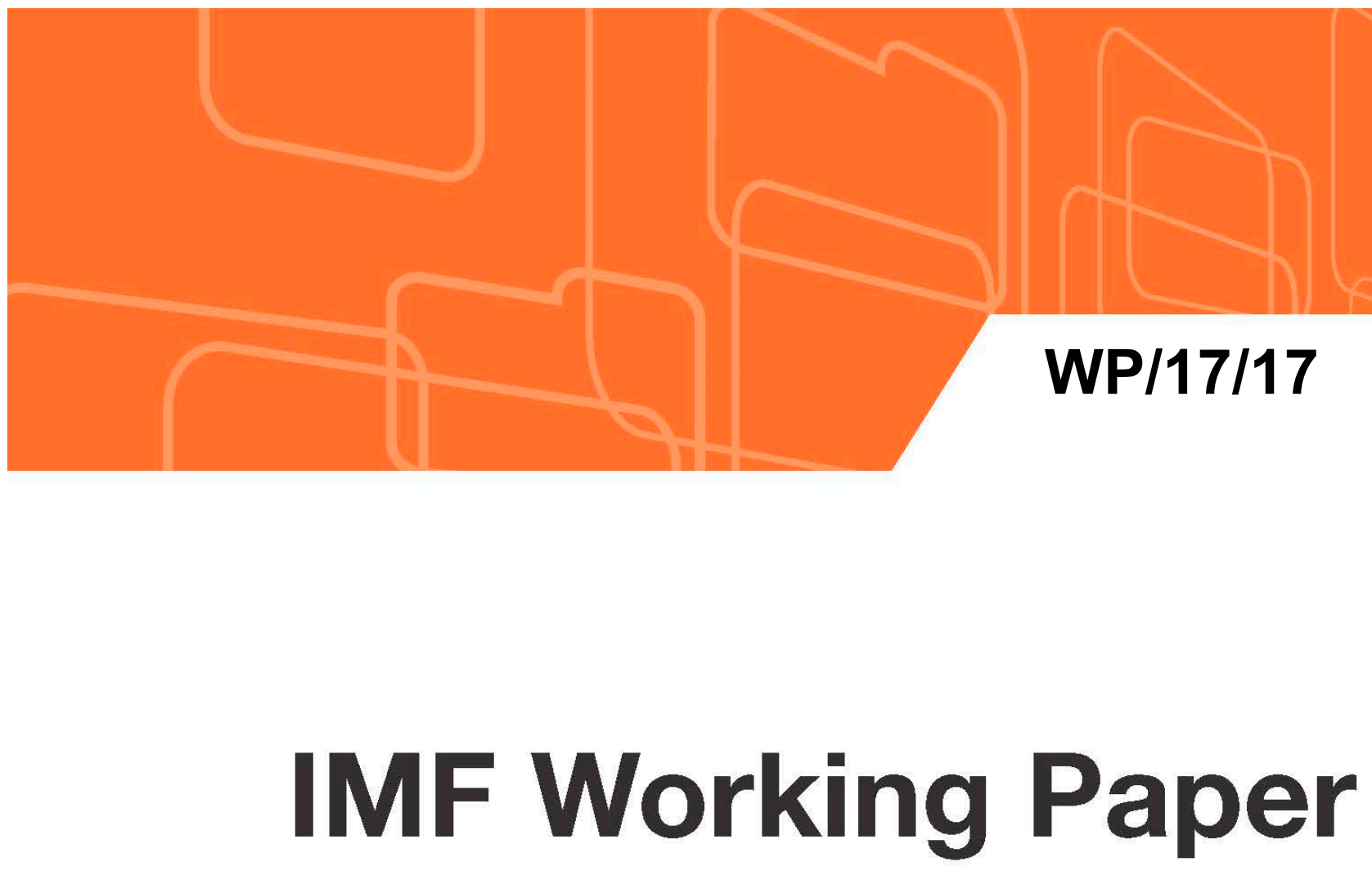

\title{
Corporate Restructuring and Its Macro Effects
}

By Jongsoon Shin

IMF Working Papers describe research in progress by the author(s) and are published to elicit comments and to encourage debate. The views expressed in IMF Working Papers are those of the author(s) and do not necessarily represent the views of the IMF, its Executive Board, or IMF management. 


\title{
IMF Working Paper
}

Asia and the Pacific Department

\section{Corporate Restructuring and Its Macro Effects \\ Prepared by Jongsoon Shin ${ }^{1}$ \\ Authorized for distribution by Kalpana Kochhar}

January 2017

\section{IMF Working Papers describe research in progress by the author(s) and are published to elicit comments and to encourage debate. The views expressed in IMF Working Papers are those of the author(s) and do not necessarily represent the views of the IMF, its Executive Board, or IMF management.}

\begin{abstract}
This paper describes issues in Korea's corporate sector, the need for restructuring, and the authorities' initiatives and challenges. It then identifies lessons from other countries' experience and conducts an econometric analysis based on cross-country aggregate data, compared with previous studies which mostly use firm-level data. This analysis finds that restructuring episodes, while sometimes challenging in the short term, have typically been associated with more rapid economic growth afterward. Corporate restructuring could have a negative effect on the labor and the financial markets in the short term, but is associated with positive growth through increased investment and capital productivity in the medium term, outpacing the negative effects.
\end{abstract}

JEL Classification Numbers: C33, E22, E23, G34

Keywords: Corporate debt, restructuring, macro effects, investment, unemployment.

Author's E-Mail Address: jshin2@,imf.org

\footnotetext{
${ }^{1}$ The author thanks Kalpana Kochhar and Koshy Mathai, as well as Ding Ding, Rui Mano, Lev Ratnovski, Edda Zoli, Dongyeol Lee, and participants of the seminar at the Bank of Korea (June 2016) for helpful comments. Any errors are the author's responsibility.
} 


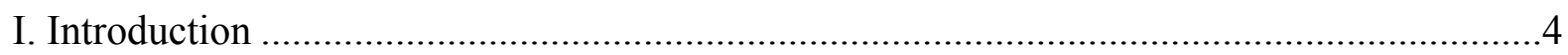

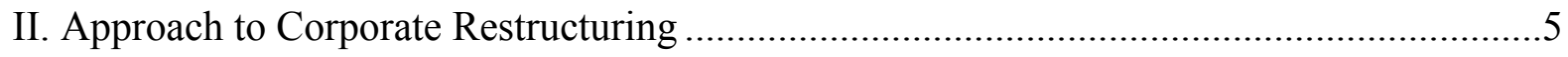

III. Corporate Condition and Restructuring in Korea ...................................................6

IV. Lessons from Corporate Restructuring in Other Countries .......................................11

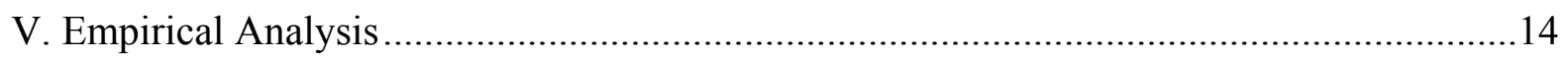

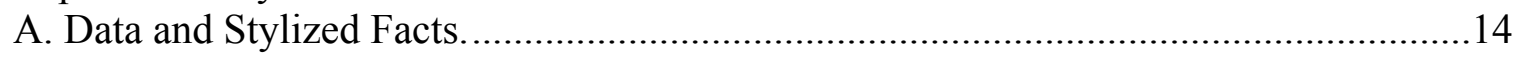

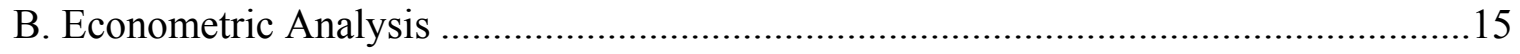

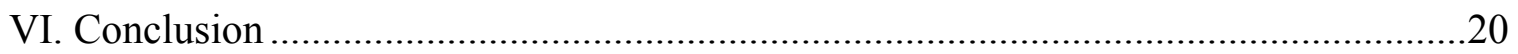

Tables

1. Impacts of Corporate Debt Restructuring on Per Capita Real GDP ................................17

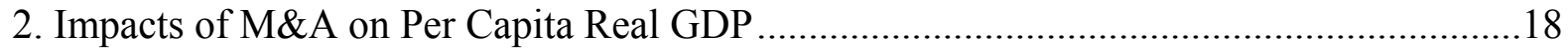

3. Impacts of Corporate Debt Restructuring on Unemployment ........................................19

4. Impacts of Corporate Debt Restructuring on Investment and Capital Productivity ............20

Figures

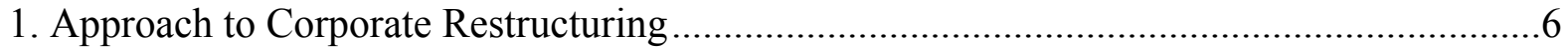

2. Key Elements of Corporate Restructuring .......................................................... 14

Appendices

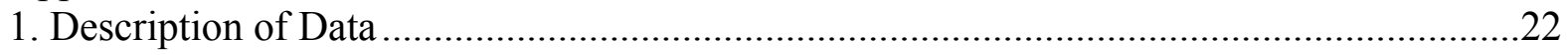

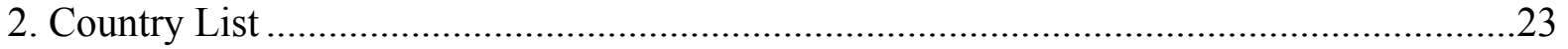




\section{INTRODUCTION}

Corporates in Korea have faced significant challenges due to sluggish global trade and rising competition from emerging markets, particularly China. Korean corporates benefitted from low-cost labor inputs and supportive policy lending as well as an export-led growth model and a good match in a world of expanding trade. However, waning global trade and rising competition from corporates in emerging market economies such as China have been posing significant challenges to the Korean corporate sector. Some of the heavy industrial sectors that underpinned Korea's past growth — for instance, shipbuilding and shipping — are confronting uncertain prospects. As in other countries, these and other industries - including the steel and petrochemical industries - have struggled with excess capacity. While Korean corporates overall appear relatively healthy, some corporates appear to require restructuring. Against this backdrop, the authorities and corporates alike have stepped up efforts to restructure debt-distressed firms in multi-pronged ways. Corporate restructuring is a daunting task, however, given its substantial uncertainty arising from the business outlook and its impact on employment and business lines.

A number of countries have been through similar challenges and restructuring periods, which could provide useful references. Japan underwent major corporate restructuring in the early 2000s after slow periods of corporate restructuring in the 1990s, which was possibly considered as one of the factors that slowed economic growth (Caballero, 2008). Spain also faced the collapse of property developers in the aftermath of the Global Financial Crisis in 2008, which led to a shift in the corporate restructuring framework. Based on corporate restructuring in various countries, literature finds that timely restructuring is important, where the financial supervisory authorities play a key role to encourage banks to carry out loan restructuring (Inoue, 2008), including clear guidelines to facilitate a collective process for workouts (e.g., the so-called London Approach); the financial soundness of banks is also critical, as it enables banks to take earlier action; and it is important for there to be flexibility in out-of-court restructuring (Grigorian, 2010). Market infrastructure is key, particularly the role of the financial markets in normal times (i.e., M\&As, or buyout funds) and transparent disclosure of corporate business conditions, as observed in the United States. Successful restructuring has also encompassed multi-faceted debt restructuring approaches (Eagle, 2014). Overall, corporate restructuring experience highlights the role of financial supervisors and government policy; soundness of banks; market infrastructure; and the dimension of firm restructuring.

\section{In regards to the effect of restructuring, literature finds that corporate restructuring could have a positive effect on investment, while debt overhang has a negative effect on investment. Literature generally finds that corporate's weak balance sheets have a negative effect on investment (Vermeulen 2000; Goretti and Souto 2013). Goretti and Souto (2013) use firm- level data by estimating the impact on the investment-to-capital ratio from debt overhang proxied by debt-to-equity and interest coverage ratios, and find that debt overhang has a negative impact on a firm's investment-to-capital. Coricelli and others (2010) find that high leverage of firms could lower growth through a higher likelihood of financial distress and bankruptcy. Bernanke and others (1999) comment that firms' weak balance sheets can act as a drag on investment and}


amplify shocks, which is framed as a financial accelerator. Kim (2003) estimates that by using firm-level data, output gains of corporate restructuring over the medium term is larger than its short-term costs. Choi and Han (2013) find that based on firm-level data, significant positive abnormal returns are realized on the announcement of spin-ins, one of restructuring methods.

This paper takes stock of recent challenges for Korean corporates and progress in corporate restructuring; relating international experience; and estimates the macro effects of corporate restructuring through cross-country panel fixed effects models. In its empirical analysis, this paper tries to answer the following questions: What are the macro effects of corporate restructuring and whether they have a positive effect or negative effect in the short term or in the medium term; if corporate restructuring has a positive effect on growth, what would be the possible channels: if corporate restructuring has a negative effect, what would be the possible channels; what would be the effect of a rise in mergers and acquisitions on growth. Compared with previous studies which mostly use firm-level data, the empirical analysis of this paper runs cross-country panel fixed effects models for 33 advanced economies from 1992-2012 to estimate the effects of corporate restructuring on growth, investment, capital productivity, and unemployment. The model estimates the effects of a reduction in aggregate corporate debt-to-equity on real GDP growth, and the effects of systemic debt reduction periods, framed as a corporate restructuring dummy, on real GDP growth. The paper also estimates the impacts of mergers and acquisitions (M\&A) on growth.

\section{APPROACH TO CORPORATE RESTRUCTURING}

\section{Corporate restructuring is a set of discrete decisive measures to increase a firm's} competitiveness and enhance its value, and can take place at various levels. Corporate restructuring also entails an improvement in operational or financing structure, to transform a firm into one that is of higher value, or to survive when a corporate's business structure becomes dysfunctional (Crum and Goldberg, 1998; Vyas, 1997).

Restructuring can take place at different levels. At the whole economy level, it is a long-term, systemic response to technological changes, market trends, and macroeconomic conditions. At the industry level, changes in the production structure and new arrangements across firms could be a trigger. At the firm level, the need to adapt to new market conditions could require new business strategies and internal business reorganization (Vyas, 1997).

Corporate restructuring can be also categorized as operational restructuring, financial restructuring, and investment restructuring (Vyas, 1997). Operational restructuring can be undertaken by reducing labor and production costs, improving the production mix or introducing new products, or enhancing distribution channels. Investment restructuring leads to changes in fixed capital or working capital investment. Financial restructuring entails reduction of debt, injections of capital, debt to equity swaps, restructuring of debt including a reduction in interest rates, longer maturities, or partial debt write-downs, asset sales, or equity issues. These sets of restructuring can be undertaken in parallel. 
In practice, corporate restructuring can take various forms, such as financial restructuring, mergers, acquisitions, divestitures, or buy-outs, a process of redesigning a firm's business lines and organization. In the case of debt restructuring, corporate debt restructuring could be categorized as formal restructuring or informal restructuring (Figure 1). Formal restructuring could be bankruptcy or liquidation. Informal restructuring could include either debt transfers to a government agency, work-out department, or bank subsidiary, debt-for-debt swaps, equity-for-debt swaps, or debt sales.

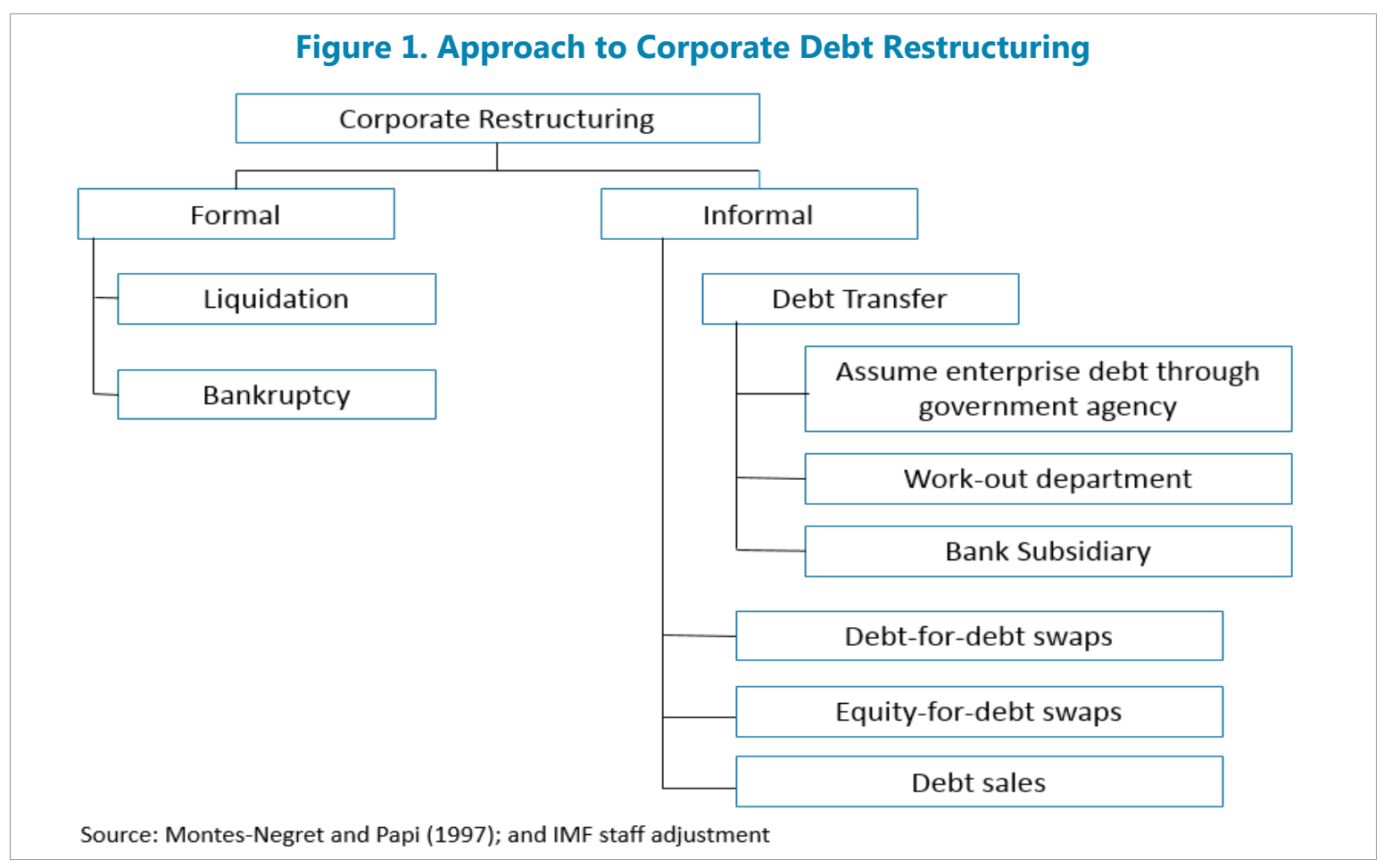

\section{Corporate Condition ANd Restructuring in Korea}

In Korea, the corporate sector in aggregate appears to be healthy, but pockets of vulnerabilities have arisen. Overall corporate leverage remains relatively low. Profitability, however, has fallen since 2010, partly due to sluggish global trade and rising competition from emerging markets, particularly China. This is in contrast with other advanced economies where profitability remains stable or has improved. Rising vulnerability has been more pronounced in weaker segments of corporates. Weaker firms have become more leveraged, while their profits have declined sharply. This is in contrast with Japanese firms, which have seen a recovery in profitability and a reduction in leverage since 2010 . 

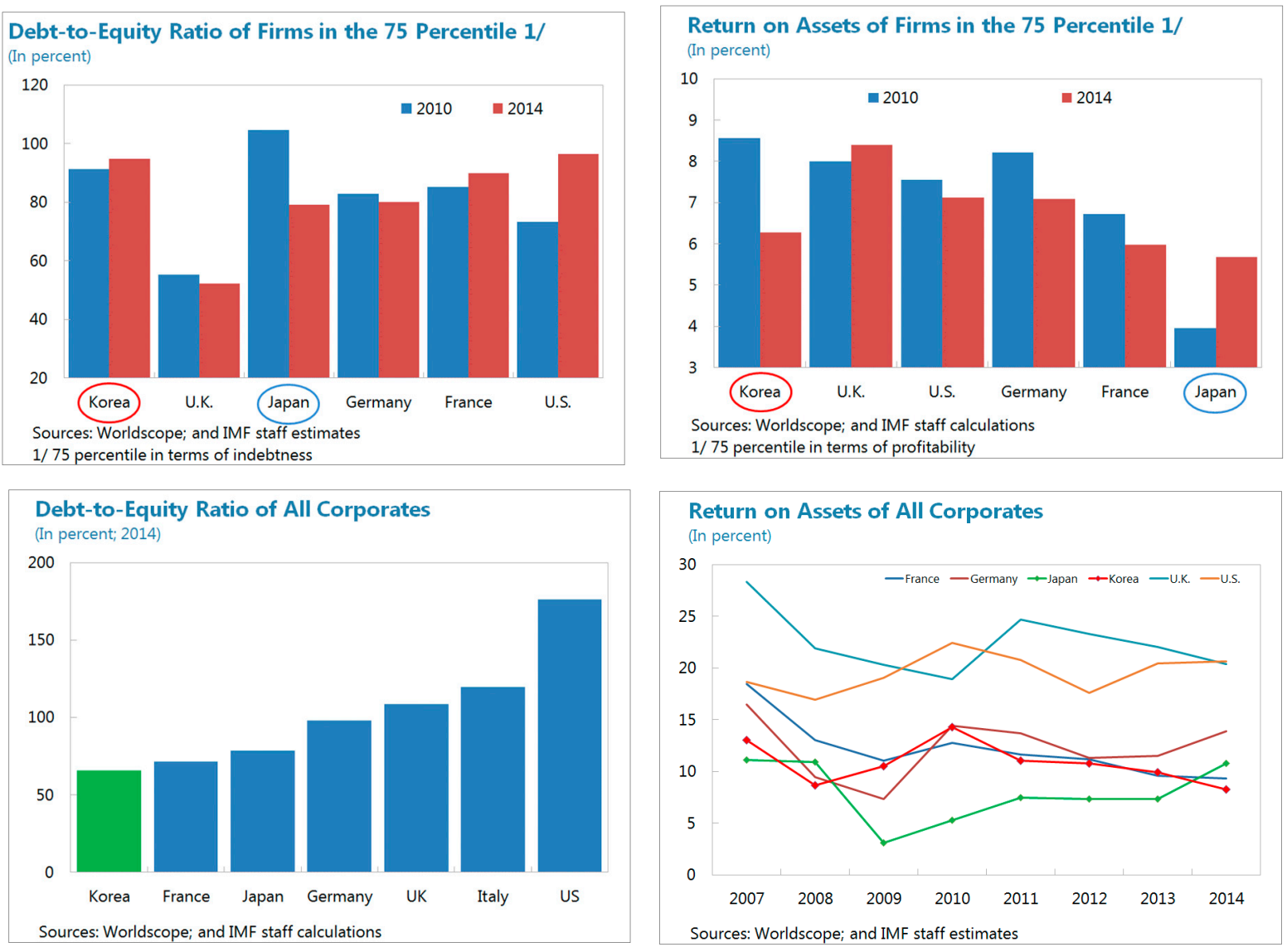

\section{However, corporate performance has been under particular pressure in a few}

industries. The shipbuilding, shipping, petrochemical, steel, and construction industries have been affected by slowing global trade, competition with Chinese firms, and global overcapacity. Some of the largest corporates in the shipbuilding and shipping sectors have recently posted their worst performances, with record losses, plummeting revenues, elevated leverage, and a liquidity squeeze.
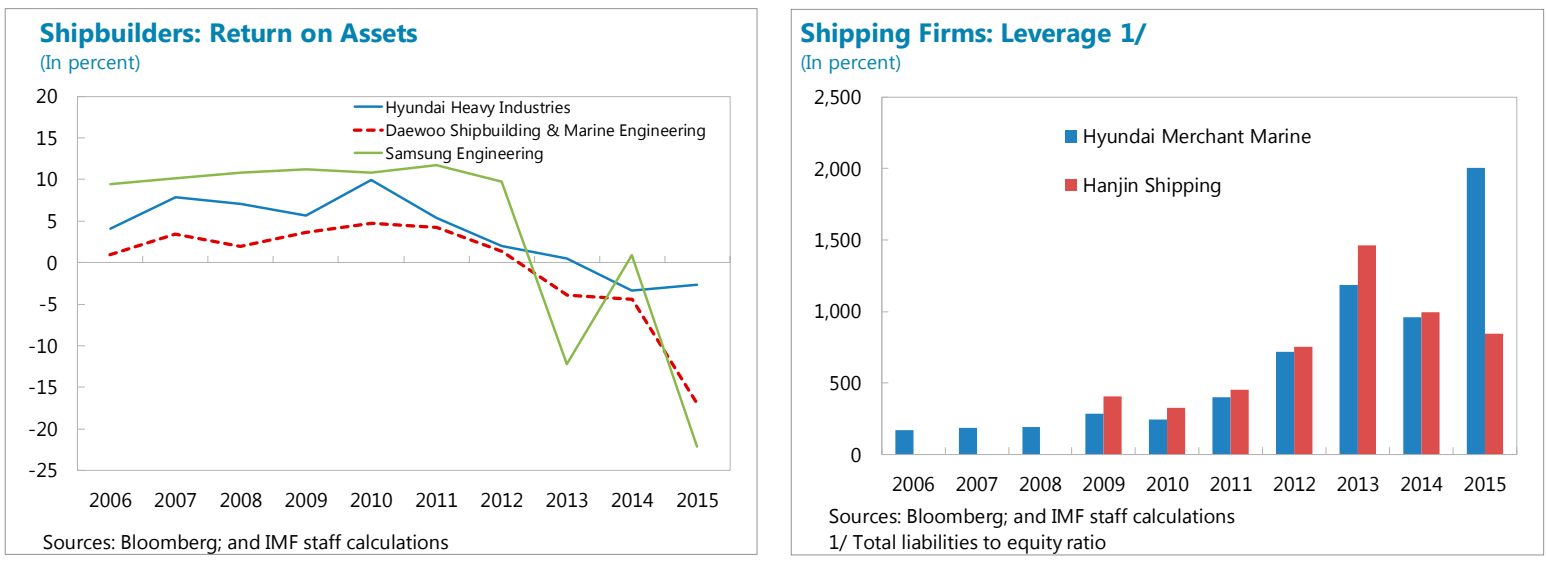


\section{While credit risks have risen, policy banks have large exposure to the vulnerable} sectors. Against the backdrop of weakening performance, most of the firms' credit ratings have been downgraded, suggesting a heightened credit risk to the banking sector. Banks' credit to the shipbuilding and shipping firms is large. Two policy banks in particular, Korea EXIM and KDB, have substantial lending - W 38 trillion (2 $\frac{1}{2}$ percent of GDP) and W 20 trillion (11/4 percent of GDP), respectively, as of March 2016 - and have been facing potential loan losses, which could affect their capital position and policy lending capacity.
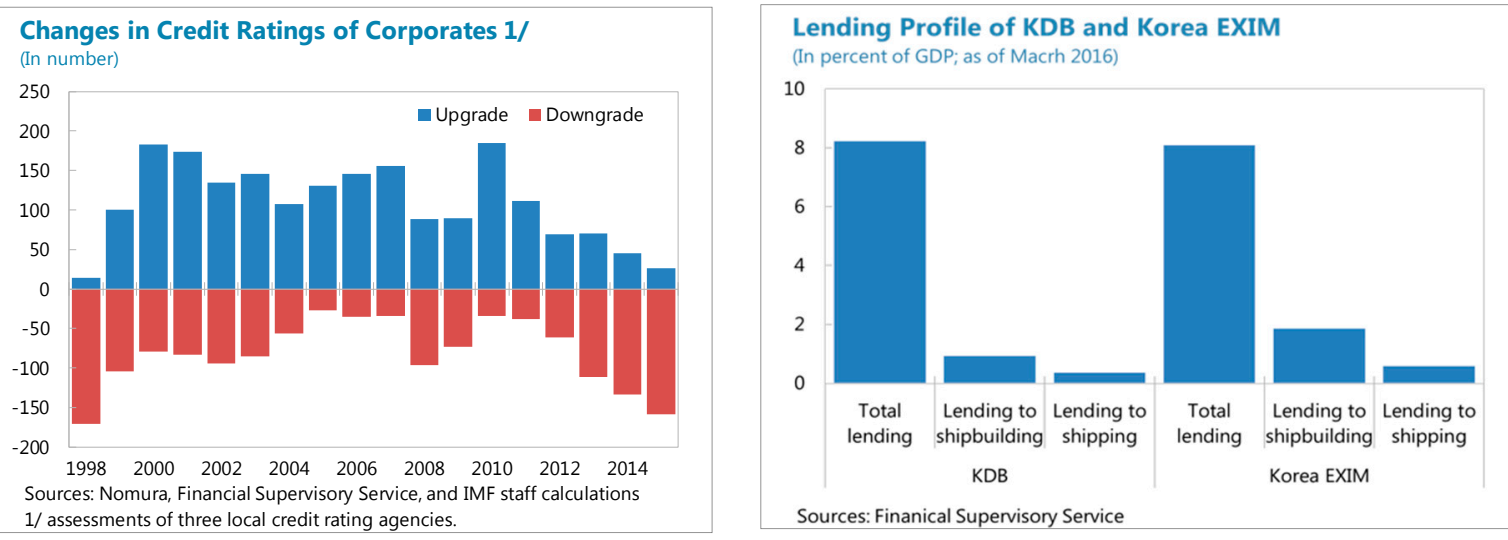

The authorities have made arrangements for policy bank recapitalization, building on their similar experience in early 2009.

- The Bank Recapitalization Fund in 2009. In the aftermath of the Global Financial Crisis, the government established the Bank Recapitalization Fund, in order to mitigate growing concern over commercial banks' capital position amid uncertain financial markets. While the size of the fund was envisaged as up to W 20 trillion-with financing from up to $\mathrm{W} 10$ trillion from the Bank of Korea, W 2 trillion won from $\mathrm{KDB}$, and $\mathrm{W} 8$ trillion from

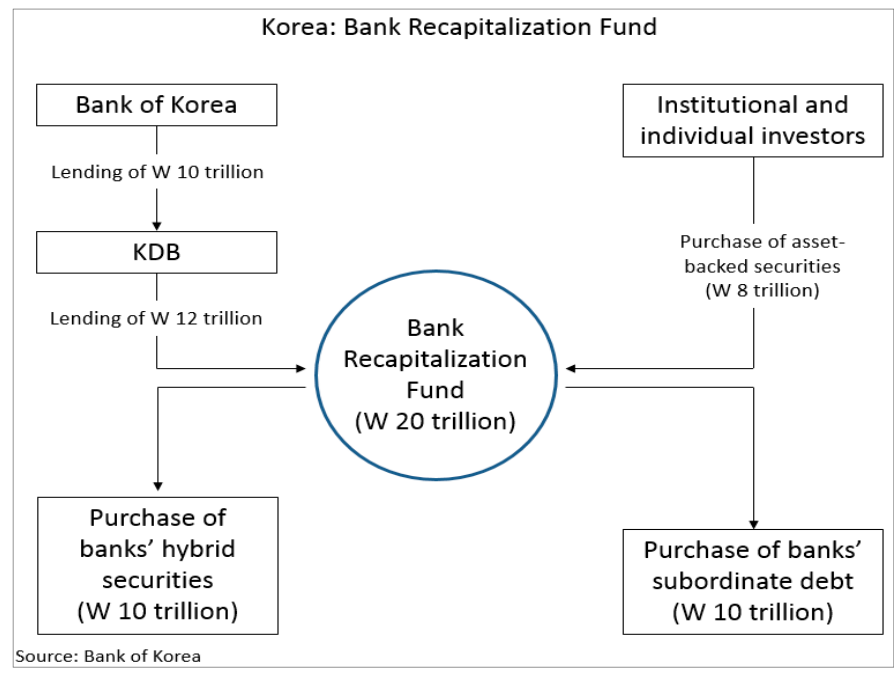
investors - the BOK lent short-term loans of W 3.3 trillion and KDB provided loans of W 0.7 trillion. The fund purchased hybrid securities of W 3.5 trillion and subordinate debt securities of W 0.5 trillion of eight commercial bank or regional banks. The fund was in operation through 2014. 
- The Policy Bank Recapitalization Fund in $2016 .^{2}$ The authorities have taken preemptive action to safeguard the capital position of the policy banks through a policy-mix of direct capital injection and the Policy Recapitalization Bank. The government plans to use the supplementary budget to provide W 1 trillion to Korea EXIM and W 0.4 trillion to KDB. Also building on the experience from the 2009 fund, the government has set up the Policy Bank Recapitalization Fund of up to W 11 trillion, as a part of a contingency plan that aims to cope with the possible systemic risks. The fund will be financed by $\mathrm{W} 1$ trillion in loans from the Industrial Bank of Korea, as well

Korea: Framework for Recapitalization of Policy Banks $1 /$

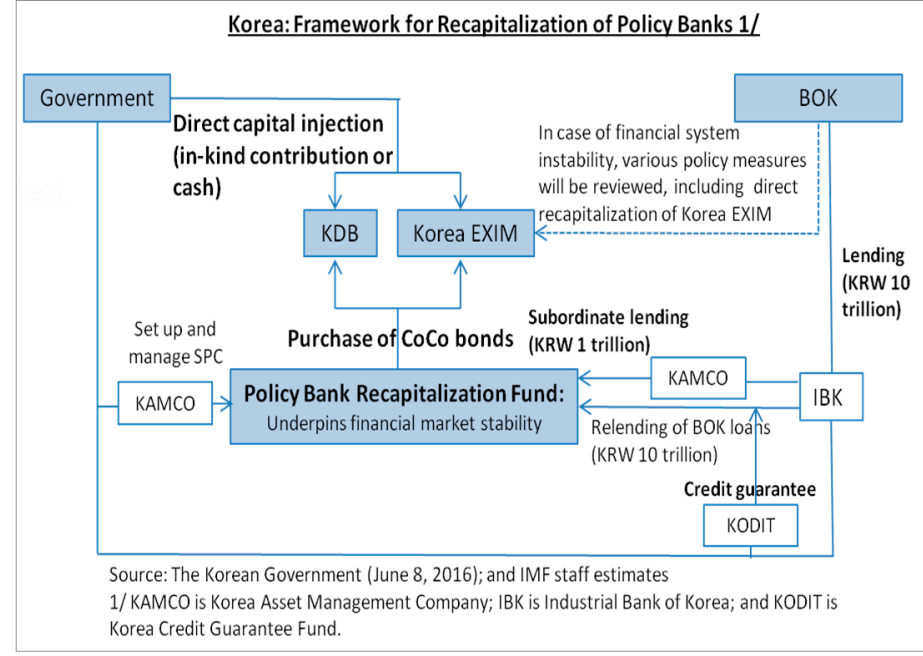
as up to $\mathrm{W} 10$ trillion in short-term loans from the BOK. The fund will purchase policy banks' Tier 1 or Tier 2 contingent convertible $(\mathrm{CoCo})$ bonds, on a capital-call basis. The size and actual use of the fund will depend on the extent and speed of corporate restructuring, in addition to the credit conditions of the vulnerable industries. The fund will likely be in operation through end-2017, and may be changed during the end-year review of the fund.

At the same time, the government has formed a 3-track restructuring strategy, based on urgency and risk, aiming to focus on key risks and facilitate industry-wide restructuring.

- Track 1 is to deliver industry-wide restructuring in cyclically sensitive industries - the shipbuilding and shipping industries. As the policy banks are the main creditor banks, the public sector is naturally closely involved in Track 1 restructuring. The main creditor banks encouraged debt-distressed firms to come up with a comprehensive revitalization plan. The three major shipbuilding firms, as a result, revealed revitalization plans, including the sale of non-core assets, business reorganization, and downsizing, amounting to W 10.3 trillion ( 0.7 percent of GDP). The major shipping firms have also reached a debt reduction agreement with creditors or negotiated charter fees.

\footnotetext{
${ }^{2}$ See staff report for the Korea 2016 Article IV consultation, Box 2: The Authorities' Plan for Shoring up the Capital of Policy Banks.
} 
- Track 2 is to restructure individual weak firms, rather than an industry itself, through banks' regular credit assessment under supervision of financial supervisors. Based on the Corporate Restructuring Act, banks assess credit risk and reach an agreement with vulnerable debtors on financial restructuring, possibly through workout or rehabilitation programs.

Against this backdrop, the number of

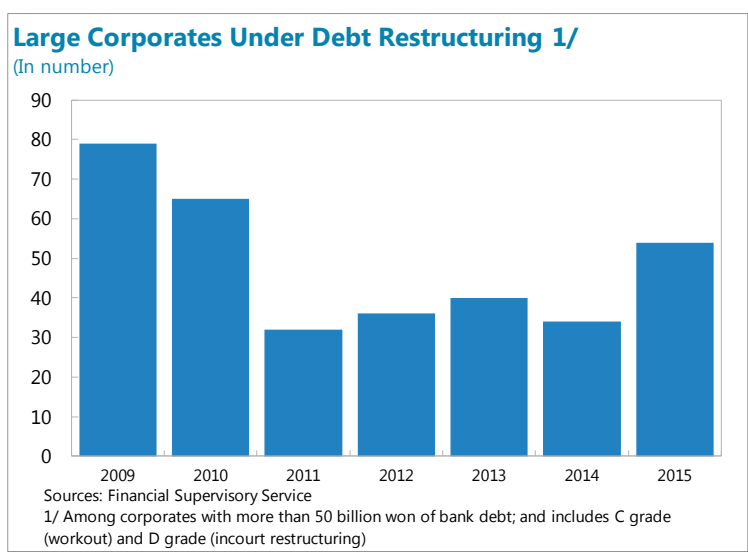
corporates under debt restructuring rose to 229 as of end-2015 (including 54 large corporations), from 159 firms in 2014.

Track 3 is to pursue preemptive industry restructuring through mergers and acquisitions (M\&A), downsizing, or business line exchanges, to address overcapacity problems, such as in the petrochemical or steel industries. This will be led by the industry itself, especially industry associations. The Corporate Vitality Enhancement Act (also known as the "One-Shot Law"), effective August 2016, should facilitate M\&A and restructuring through streamlined legal procedures for M\&A, spinoffs, and equity transfers, as well as tax incentives (e.g., deferral of capital gains tax from equity transfers, and installment payments of transfer gains tax).

\section{While Korea is well placed to address corporate vulnerabilities thanks to a strong institutional environment, progress has been slower than desired. Korea has had a good track record of corporate restructuring in the past and has further improved the restructuring framework. Despite worsening corporate conditions since 2011, however, restructuring efforts have started to take place only rather recently. Changing global market conditions have raised questions about the prospects for certain sectors and Korea's appropriate positioning in them, and against that background, corporate restructuring has been extremely difficult. Some banks tended to delay loan restructuring on account of the highly uncertain industry outlook and fear of substantial loss realization. There has been a concern as to the negative effect on employment and regional economies as well as potential difficulties for major firms. Notwithstanding the progress already made in the corporate restructuring framework, some further areas for institutional improvements - drawing on the international experience-include:}

- A larger role for capital markets in normal times. In many countries, restructuring tends to be delayed in normal times until the realization of debt distress and heavily relies on legal, institutional arrangements. This often requires large-scale government intervention and taxpayers' money, resulting in larger costs. The role of private equity funds is limited, as their small size is insufficient to take over large firms. M\&A activity has been traditionally low, despite a recent pickup, and the non-performing-loans market remains underdeveloped. 
- Continuing to strengthen the out-of-court restructuring framework. While firms have growingly tapped into market funding such as bonds and commercial paper, the out-of-court restructuring framework hinges on the role of the main creditor banks. Uncertainty arises, therefore, regarding a loss sharing between bank creditors and nonbank creditors, as banks have less incentive to initiate debt restructuring and bear the brunt of restructuring (Cho, 2013). Literature finds that a stronger bank relationship could make the restructuring process easier, which suggests growing market financing may render restructuring more complicated. According to Huang and Huang (2011), a stronger bank relationship has a greater probability for successful debt restructuring through private renegotiation. Demiroglu and James (2015) also find that traditional bank loans are significantly easier to out of court restructuring than institutional lender loans, and that firms that rely on syndicated loans are harder to restructure. In this sense, Korea's revised Corporate Restructuring Promotion Act, which came into effect in March 2016, will help address some of these problems, by extending the coverage of creditors to all the creditors including bond creditors and offshore financial institutions, and strengthening the role of the main creditor banks through a right to request other creditors to freeze the exercise of creditor rights. Going forward, it is essential to building up good track records of out-of-court restructuring under the new law.
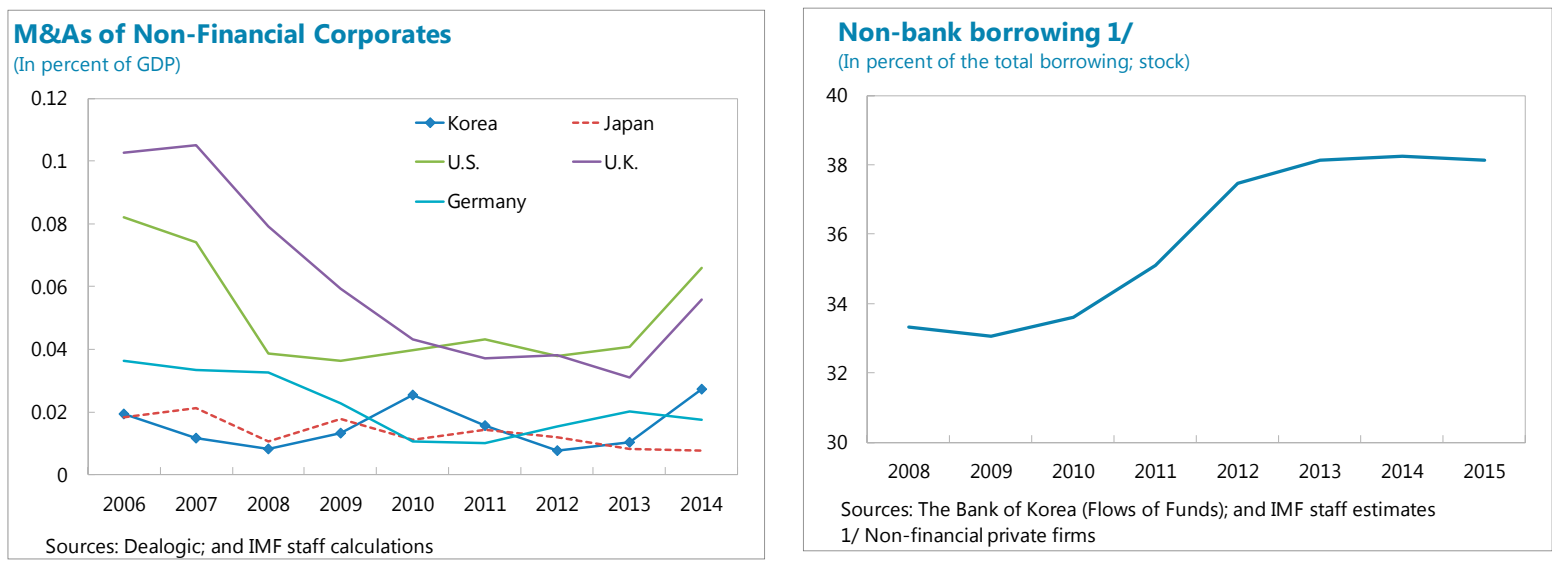

\section{LESSONS FROM CORPORATE RESTRUCTURING IN OTHER COUNTRIES}

Corporate restructuring experience in other countries highlights the role of financial supervisors and government policy; banking soundness; market infrastructure; and the dimension of firm structuring. Literature broadly finds the following lessons:

\section{The role of financial supervisors and government policy}

- Swift, timely restructuring is crucial to remove uncertainty. Delayed corporate restructuring and slow balance sheet repairs could result in sluggish investment and weak productivity growth (Hoshi and others, 2009; Caballero and others, 2008). 
- The role of financial supervisors. The financial supervisory authorities should play a proactive role to encourage banks to carry out loan restructuring, notably through debt-equity swaps (Inoue, 2008).

- Risks/costs of government intervention. Literature broadly discusses the risks of potential costs of government involvement. Government ownership, which may result from the assumption of a debt distress private firm, is associated with costs and government intervention could come at a cost. Grigorian and others (2010) suggest that the cost of government intervention in corporate rescue could be significant, and state-owned enterprises (SOEs) tend to incur higher debt costs (Borisova and others, 2015; and Kam and others., 2008).

- Supportive fiscal policy. An unfavorable macroeconomic environment - notably the sluggish property markets seen over the past years - could make it more difficult for creditor banks and corporates to resolve assets and reorganize business lines. Also a rise in unemployment associated with corporate restructuring could make restructuring more difficult and painful. In this context, supportive fiscal policy, including enhancing the social safety net, may be helpful to incentivize and facilitate restructuring.

Soundness of the banking sector

- Banks' soundness and their credit risk management tend to have a profound effect on the speed and degree of corporate restructuring. Banks may have incentives to delay loan restructuring for fear of loss realization and a rise in NPLs. In this sense, banks' sufficient capital position is key to restructuring debt, and the government may need to step in to enforce timely recognition of losses and to recapitalize banks, in case it is not feasible for shareholders to recapitalize the bank (Laryea, 2010).

Legal and market infrastructure.

- Clear guidelines and proper legal framework. Reform of the insolvency and other related laws support out-of-court restructuring, where feasible, and it is essential to enable a speedy out-of-court restructuring to be accepted by a qualified majority of creditors and bind dissenting creditors (Laryea, 2010). In this context, it will be helpful to extend clear guidelines that facilitate a collective process for workouts (e.g., the so-called London Approach in the U.K.) to non-financial creditors. Financial deregulation can also provide supports to restructuring. In Japan, for example, firms' spin-ins contributed to improvements in investment, assisted by financial deregulation, which helped diversify corporate financing from bank financing to market financing, making corporates' internal structure more efficient (Choi and Han, 2013).

- Market infrastructure. The transparent, reliable disclosure of firms' business and financial conditions, and the deepening of the financial markets (i.e., M\&A, or buyout funds) play important roles to facilitate corporate restructuring in normal times, as in the 
case of the United States. Kim (2003) also estimates that the positive effects of corporate restructuring could be larger with broader reforms, including in financial disclosure, enhanced corporate transparency, and more active M\&A markets. The positive effect of M\&A activity on growth is discussed in the panel estimates in the following section.

- Tax regime. Tax issues can be a factor to facilitate business restructuring, as favorable tax treatment on debt restructuring or write-offs could lead creditors to write off more debt. According to Johnson (2005), favorable tax treatment can incentivize a firm to create a structure better suited to a restructuring and risk and asset reallocation. Also countries with a common law system (e.g., the United States, United Kingdom, Australia) tend to provide more favorable and comprehensive tax treatment for debt write-offs, whereas countries with a civil law system (e.g., Japan, Germany, France) have less favorable tax regimes to debt write-offs, rendering the business environment less conducive to restructuring (Johnson, 2005).

\section{Dimension and degree of firm restructuring.}

- A multi-faceted debt restructuring approach. According to Eagle (2014), recent restructuring in the shipping industry covers multi-dimensional approaches encompassing financial and operational restructuring, including: lenders collaborating with shipping firms to restructure; the Chapter 11 U.S. bankruptcy process which affords protection being widely used to facilitate restructuring; some lenders selling debt portfolios; a significant role of private equity and hedge funds; and a setup of shipping investment funds. In addition, general cost-saving measures were undertaken; disposing of non-core assets and restructuring fleets to focus on vessels which are in high demand; maintaining cash reserves and securing funding lines (including funding from shareholders/equity); waiving debt covenants from financiers, simultaneous restructuring of capital reorganization; and disposing of non-core or non-performing assets to reduce bank debt.

- Business reorganization. Cross-industry restructuring can be very effective. By narrowing their product focus and reducing their product cycle, corporates are able to restructure and attract investors (Vyas, 1997). Daley and others (1997) find that operating performance for cross-industry spinoffs, rather than own-industry cases, could lead to a significant improvement, and that this is possible by removing unrelated businesses and allowing managers to focus attention on the core operations they are best suited to manage.

- Management's reliability and competency. It is critical to set the right management in place during restructuring periods. Blazy and others (2014) find that two essential elements of a successful debt renegotiation are the management's reliability and competency, and the role of market oriented managers is key in restructuring firms (Vyas, 1997).

In sum, corporate experience highlights the role of financial supervisors and government 
policy; the banking sector's soundness; legal and market infrastructure; and the dimension and degree of firm structuring, as seen in Figure 2.

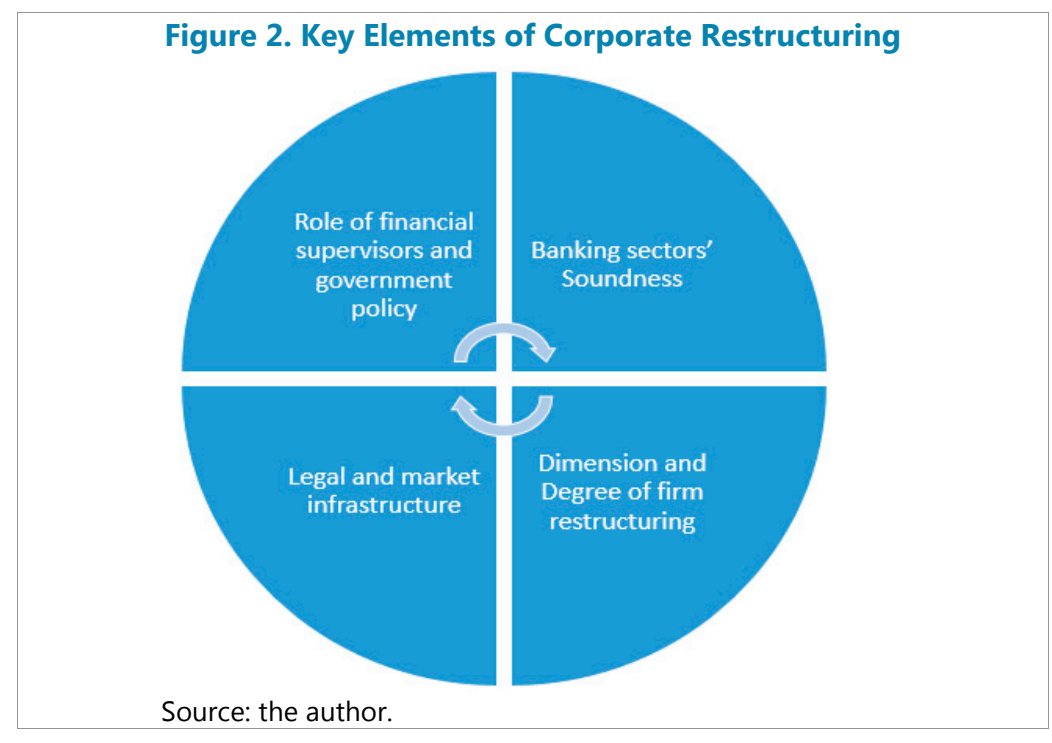

\section{EMPIRICAl ANALYSIS}

\section{A. Data and Stylized Facts}

Data for the main variables, including per capita real GDP, purchasing-power-parity (PPP) GDP per capita, investment to GDP, the fiscal balance, and government debt, are drawn from the IMF's World Economic Outlook database (January 2016). Capital productivity data come from OECD; aggregate corporate debt-to-equity data are obtained from Worldscope; and data on mergers and acquisitions come from Dealogic. Crisis dummy data come from a previous study of Laeven and Valencia (2012), and financial institution depth data are based on a previous study of Svirydzenka (2016). For more details, please see Appendix 1. The analysis is based on a panel of 33 advanced economies from 1992-2012 with annual data sets.

The data suggest that there is a positive relationship between a reduction in initial debt-to-equity and subsequent real per capital GDP growth. A scatterplot of initial aggregate corporate debt-to-equity and real per capital GDP growth is created from the sample of 33 advanced economies from 1991-2014. Given the OLS fitted line, the coefficient of initial corporate debt-to-equity is around -0.009 , possibly suggesting that a 10 percentage decrease in initial corporate debt-to-equity could be associated with a subsequent increase in real per capital GDP of around 0.09 percentage points, with caveats that these are not controlled for other variables. M\&A activity also seems to have a positive relationship with per capita real GDP growth. The OLS fitted line suggests that a 10 percent increase in M\&A activity could lead to a 0.02 increase in real per capital GDP growth with a lag of two years.

Data show that a reduction in initial debt-to-equity has a positive relationship with an increase in investment with a lag of one year. Based on the OLS fitted line, the coefficient of 
initial corporate debt-to-equity is around -0.53 , possibly suggesting that a 10 percentage reduction in initial corporate debt-to-equity could be associated with a subsequent increase in investment-to-GDP of around 5.3 percentage points, though these are not controlled for other variables. Also a positive relationship is observed in a reduction in debt-to-equity and an increase in capital productivity. The OLS fitted line suggests that a 10 percent reduction in debt-to-equity could be linked with a subsequent rise in capital productivity of around 9 percentage points, also without being controlled for other variables.
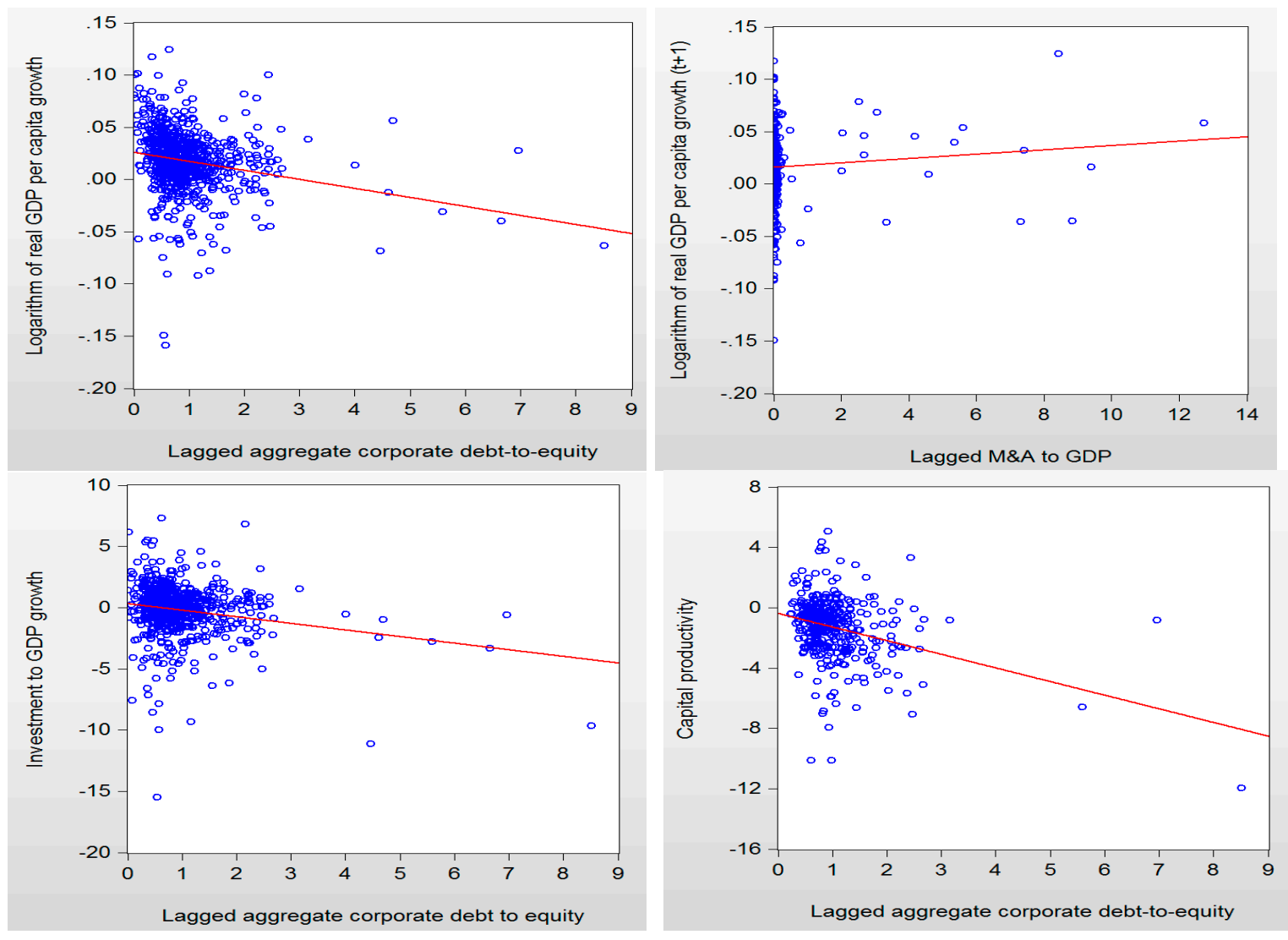

\section{B. Econometric Analysis}

\section{Model Specification}

To estimate the impact of corporate debt restructuring on growth, panel fixed effects models for the 33 advanced economies from 1992-2012 is set up. This model refers to an approach adopted in Woo and Kumar (2015), which estimates the impact of high public debt on economic growth in a country panel model, and finds that high initial public debt has a negative impact on subsequent economic growth. Instead of public debt to GDP, aggregate corporate debt-to-equity and a dummy variable for corporate restructuring periods are introduced, while a similar set of variables are used to control other effects, such as government debt and the fiscal deficit. The model is as follows: 


$$
\begin{aligned}
Y_{i, t}-Y_{i, t-1}= & \beta_{1}+\beta_{2} Y_{p i, t-1}+\beta_{3} D / E_{i, t-1}+\gamma_{1} D U M_{B C i, t-1}+\gamma_{2} D U M_{C D R i, t-1} \\
& +\gamma_{3} D U M_{C D R i, t-1} \times F I D_{i, t-1}+\delta_{t} M \& A / G D P_{i, t-1}+\varepsilon_{1} X_{i, t-1}+\epsilon_{t}+\theta_{i} \\
& +\mu_{i, t}
\end{aligned}
$$

The model estimates the effects of a reduction in debt-to-equity $(\mathrm{D} / \mathrm{E})$ and a corporate restructuring period (DUM $\left.\boldsymbol{M}_{C D R}\right)$ on growth. ${ }^{3} Y$ denotes the logarithm of per capita real GDP, and $Y p$ denotes the logarithm of purchasing-power-parity (PPP) per capita GDP, where $\mathrm{t}$ denotes a year and $\mathrm{i}$ denotes a country. In order to avoid a causation problem, lagged variables are estimated. A corporate restructuring dummy $\left(D U M_{C D R}\right)$ is defined as a more than 12 percent decline $(\mathrm{y} / \mathrm{y})$ in debt-to-equity $(\mathrm{D} / \mathrm{E})$ of 75 th percentile firms in a given year, which is in line with corporate restructuring episodes in the countries in the panel. This matches with corporate restructuring periods experienced in sample countries, including Korea (1998-1999 and 2009), Japan (2004), Sweden (1991-1992, 1994), Finland (19931996), and Iceland (2010). To estimate spillovers through the financial sector, financial channel effects are estimated via an interaction term $\left(D U M_{C D R} \times F I D\right)$, where $F I D$ denotes financial institution depth indicators (Svirydzenka, 2016). To control the impact of a banking crisis on growth, a banking crisis dummy, denoted as $D U M_{B C i, t-1}$, is added to address endogeneity (Laeven and Valencia, 2012). $X_{i, t-1}$ is a vector of fiscal factors such as initial government debt and an initial fiscal balance. Finally, $\epsilon_{t}$ is the time-specific fixed effect; $\theta_{i}$ is the country-fixed effect; and $\mu_{i, t}$ is an unobservable error term. The model also estimates the effects of M\&A on growth to capture a type of corporate restructuring that is not involved in a debt reduction.

\title{
Main Results
}

Effect of Corporate debt restructuring and $M \& A$ on growth.

\begin{abstract}
Panel 1 shows a positive relationship between corporate debt restructuring and economic growth with a time lag. Debt-to-equity has a negative and statistically significant coefficient estimate with real per capita GDP. This result suggests that a reduction in corporate leverage is associated with a positive effect on growth with a lag of one year. At the same time, the corporate debt restructuring dummy has a positive and statistically significant coefficient estimate, suggesting broad corporate restructuring periods-where debt-to-equity of 75 percentile high debt-to-equity firms drops more than 12 year-on-year percent - are followed by positive real GDP growth with a lag of one year. These are in line with other literature, for instance, Kim (2003) estimates that output gains of corporate restructuring over the medium term is larger than its short-term costs. On the other control variables, lagged initial purchasing-power-parity (PPP) per capita GDP has a negative and statistically significant coefficient estimate, in line with the income convergence theory. The
\end{abstract}

\footnotetext{
${ }^{3}$ Appendix I provides more detailed description of data.
} 
lagged banking crisis dummy has a negative and statistically significant coefficient estimate.

\section{In panel 2, other fiscal variables such as government debt and the fiscal balance are} included, but those variables do not have statistically significant estimates. Nonetheless, aggregate corporate debt-to-equity and the corporate restructuring dummy have statistically significant coefficients.

\section{In panel 3, an interaction term between the corporate restructuring dummy and the} financial sector is included, to examine whether corporate restructuring could have some spillover effect on growth through financial channels. The financial spillover interaction term has a negative and statistically significant coefficient with real GDP growth, while the corporate restructuring dummy continues to have a positive and statistically significant coefficient. These results suggest negative spillovers via financial channels could partly offset the positive impact of debt restructuring. This is possibly because tighter lending conditions and a rise in NPLs could cause deleveraging of banks, in line with findings in other literature: Coricelli and others (2010) find that high leverage of firms could lower growth through higher likelihood of financial distress and bankruptcy; and Bernanke and others (1999) state that firms' weak balance sheets can drag investment and amplify shocks, which is framed as a financial accelerator.

\begin{tabular}{|c|c|c|c|}
\hline & $\begin{array}{c}\text { Panel 1: } \\
\text { per capita real GDP } \\
\text { growth }_{\mathrm{t}} \\
\end{array}$ & $\begin{array}{c}\text { Panel 2: } \\
\text { per capita real GDP } \\
\text { growth }_{\mathrm{t}} \\
\end{array}$ & $\begin{array}{c}\text { Panel 3: } \\
\text { per capita real GDP } \\
\text { growth }_{\mathrm{t}}\end{array}$ \\
\hline Lagged initial PPP per capita GDP & $\begin{array}{c}-0.07^{* * *} \\
(0.00)\end{array}$ & $\begin{array}{c}-0.08^{* * *} \\
(0.00)\end{array}$ & $\begin{array}{c}-0.08^{* *} \\
(0.00)\end{array}$ \\
\hline Lagged banking crisis dummy & $\begin{array}{c}-0.012^{* * *} \\
(0.00)\end{array}$ & $\begin{array}{c}-0.013^{* * *} \\
(0.00)\end{array}$ & $\begin{array}{c}-0.013^{* * *} \\
(0.00)\end{array}$ \\
\hline Lagged Debt-to-equity & $\begin{array}{c}-0.005^{* * *} \\
(0.00)\end{array}$ & $\begin{array}{c}-0.005^{* * *} \\
(0.00)\end{array}$ & $\begin{array}{c}-0.005^{* * *} \\
(0.00)\end{array}$ \\
\hline Lagged Corporate restructuring dummy & $\begin{array}{c}0.004^{*} \\
(0.07)\end{array}$ & $\begin{array}{l}0.005^{*} \\
(0.06)\end{array}$ & $\begin{array}{c}0.02 * * * \\
(0.00)\end{array}$ \\
\hline $\begin{array}{l}\text { Lagged corporate restructuring dummy*financial } \\
\text { institutions development }\end{array}$ & & & $\begin{array}{c}-0.025^{* *} \\
(0.01)\end{array}$ \\
\hline Lagged government gross debt & & $\begin{array}{l}-0.005 \\
(0.51)\end{array}$ & $\begin{array}{l}-0.007 \\
(0.38)\end{array}$ \\
\hline Lagged government fiscal balance & & $\begin{array}{l}-0.027 \\
(0.49)\end{array}$ & $\begin{array}{l}-0.031 \\
(0.40)\end{array}$ \\
\hline Constant & $\begin{array}{c}0.776 * * * \\
(0.00)\end{array}$ & $\begin{array}{c}0.870^{* * *} \\
(0.000)\end{array}$ & $\begin{array}{c}0.858^{* * *} \\
(0.00)\end{array}$ \\
\hline Sample size & 586 & 551 & 551 \\
\hline$R-s q$ & 0.58 & 0.60 & 0.59 \\
\hline
\end{tabular}

\section{Corporate restructuring can be also undertaken in the form of $M \& A$, which is} positively associated with real GDP growth with a time lag. A panel fixed effect model shows that M\&A/GDP has a positive and statistically significant coefficient with real GDP growth with a lag of two years, after controlling the other factors such as income level, 
banking crisis and the other factors as discussed above (Table 2). This suggests that M\&A has a positive growth with a lag of two years. These results are in line with findings in other literature that M\&A could improve operating performance (Smart and Waldfogel, 1994), and M\&A is associated with higher productivity in acquired firms $(\mathrm{Li}, 2011)$. In the case of M\&A activity, the longer time lag effect is likely because the synergy of M\&A takes time to be realized given the integration tasks of different organizations, people, and cultures.

\begin{tabular}{|c|c|c|c|}
\hline & $\begin{array}{c}\text { Panel 1: } \\
\text { per capita real GDP } \\
\text { growth }_{t+1}\end{array}$ & $\begin{array}{c}\text { Panel 2: } \\
\text { per capita real GDP } \\
\text { growth }_{t+1}\end{array}$ & $\begin{array}{c}\text { Panel 3: } \\
\text { per capita real GDP } \\
\text { growth }_{\mathrm{t}+1}\end{array}$ \\
\hline Lagged initial PPP per capita GDP & $\begin{array}{c}-0.08^{* * *} \\
(0.00)\end{array}$ & $\begin{array}{c}-0.09 * * * \\
(0.00)\end{array}$ & $\begin{array}{c}-0.08^{* * *} \\
(0.00)\end{array}$ \\
\hline Lagged banking crisis dummy & $\begin{array}{c}-0.0011^{* * *} \\
(0.00)\end{array}$ & $\begin{array}{c}-0.012^{* * *} \\
(0.00)\end{array}$ & $\begin{array}{c}-0.011^{* * *} \\
(0.00)\end{array}$ \\
\hline Lagged Debt-to-equity & & & $\begin{array}{c}-0.0002 \\
(0.91)\end{array}$ \\
\hline Lagged Corporate restructuring dummy & & & $\begin{array}{l}0.0009 \\
(0.72)\end{array}$ \\
\hline Lagged government gross debt & & $\begin{array}{l}-0.006 \\
(0.45)\end{array}$ & $\begin{array}{l}-0.006 \\
(0.51)\end{array}$ \\
\hline Lagged government fiscal balance & & $\begin{array}{l}-0.044 \\
(0.23)\end{array}$ & $\begin{array}{l}-0.042 \\
(0.26)\end{array}$ \\
\hline Lagged M\&A to GDP 1/ & $\begin{array}{c}0.004 * * \\
(0.01)\end{array}$ & $\begin{array}{c}0.004^{* * *} \\
(0.01)\end{array}$ & $\begin{array}{c}0.004^{* * *} \\
(0.01)\end{array}$ \\
\hline Constant & $\begin{array}{c}0.83^{* * *} \\
(0.00)\end{array}$ & $\begin{array}{c}0.91^{* * *} \\
(0.00)\end{array}$ & $\begin{array}{c}0.86^{* * *} \\
(0.00)\end{array}$ \\
\hline Sample size & 471 & 455 & 452 \\
\hline $\mathrm{R}-\mathrm{sq}$ & 0.64 & 0.67 & 0.66 \\
\hline
\end{tabular}

Short-term effect of corporate debt restructuring on employment.

Despite the overall positive effect on growth in the medium-term, corporate debt restructuring could have a negative short-term effect on employment (Table 3: panel 1, panel 2). Corporate debt-to-equity has a negative and statistically significant coefficient on unemployment rates in the same period (panel 1), and the corporate restructuring dummy has a positive and statistically significant coefficient on unemployment rates in the same period (panel 2). These coefficients suggest that financial restructuring could have a negative effect on employment and financial restructuring may accompany operational restructuring. This is in line with findings in literature that firms undergoing restructuring tend to adopt real adjustments such as layoffs or cutbacks and that corporates undergoing restructuring tend to cut employment more (Hoshi and others, 2008).

The panel analysis suggests, however, that the negative effect of corporate restructuring on employment might be limited to the short term. For instance, the negative relationship between corporate debt restructuring and unemployment rates is not found in a lag of one 
year (panel 3, panel 4). This implies that debt restructuring could lead to layoffs in the short-term, but not necessarily in the medium term. Indeed, the short-term costs of corporate restructuring on unemployment are outweighed by output gains over the medium-term, as shown in Table 1. On the other hand, a rise in unemployment rates in the short-term implies that an adequate social safety net is needed. Given a negative effect on employment in the short-term, it is important for the government to assist affected workers and mitigate the negative effects of corporate debt restructuring.

\begin{tabular}{|c|c|c|c|c|}
\hline & $\begin{array}{c}\text { Panel 1: } \\
\text { Unemployment } \\
\text { growth }_{\mathrm{t}-1}\end{array}$ & $\begin{array}{c}\text { Panel 2: } \\
\text { Unemployment } \\
\text { growth }_{\mathrm{t}-1}\end{array}$ & $\begin{array}{c}\text { Panel 3: } \\
\text { Unemployment } \\
\text { growth }_{\mathrm{t}}\end{array}$ & $\begin{array}{c}\text { Panel 4: } \\
\text { Unemployment } \\
\text { growth }_{\mathrm{t}}\end{array}$ \\
\hline Initial PPP per capita GDP & $\begin{array}{c}-0.06^{* * *} \\
(0.00)\end{array}$ & $\begin{array}{c}-0.07^{* * *} \\
(0.00)\end{array}$ & $\begin{array}{c}-0.05^{* * *} \\
(0.00)\end{array}$ & $\begin{array}{c}-0.05^{* * *} \\
(0.00)\end{array}$ \\
\hline Banking crisis dummy & $\begin{array}{c}0.008^{* * *} \\
(0.01)\end{array}$ & $\begin{array}{c}0.004 * \\
(0.07)\end{array}$ & $\begin{array}{c}0.01^{* * *} \\
(0.00)\end{array}$ & $\begin{array}{c}0.009 * * * \\
(0.00)\end{array}$ \\
\hline Debt-to-equity & $\begin{array}{c}-0.003^{* *} \\
(0.01)\end{array}$ & $\begin{array}{l}-0.001 \\
(0.21)\end{array}$ & $\begin{array}{r}-0.000 \\
(0.95)\end{array}$ & $\begin{array}{l}0.002 \\
(0.12)\end{array}$ \\
\hline Corporate restructuring dummy & $\begin{array}{l}0.002 \\
(0.21)\end{array}$ & $\begin{array}{c}0.004^{* *} \\
(0.04)\end{array}$ & $\begin{array}{l}0.001 \\
(0.64)\end{array}$ & $\begin{array}{l}0.002 \\
(0.31)\end{array}$ \\
\hline Government gross debt & & $\begin{array}{c}0.04^{* * *} \\
(0.00)\end{array}$ & & $\begin{array}{c}0.04^{* * *} \\
(0.00)\end{array}$ \\
\hline Government fiscal balance & & $\begin{array}{c}-0.16^{* * *} \\
(0.00)\end{array}$ & & $\begin{array}{c}-0.20 * * * \\
(0.00)\end{array}$ \\
\hline Constant & $\begin{array}{c}0.72^{* * *} \\
(0.00)\end{array}$ & $\begin{array}{c}0.63^{* * *} \\
(0.00)\end{array}$ & $\begin{array}{c}0.60 * * * \\
(0.00)\end{array}$ & $\begin{array}{c}0.54^{* * *} \\
(0.00)\end{array}$ \\
\hline Sample size & 586 & 551 & 586 & 551 \\
\hline$R-s q$ & 0.77 & 0.84 & 0.77 & 0.83 \\
\hline
\end{tabular}

Possible channel of positive effect on growth

The panel regression results suggest that the main channel of corporate restructuring is likely to be through a rise in investment. Debt-to-equity has a negative and statistically significant coefficient on investment (panel 1), and the corporate debt restructuring dummy has a positive and statistically significant coefficient on investment, with a lag of one year (panel 2). These results are in line with findings in the literature. Highly leveraged or weak corporate balance sheets have a negative effect on corporate investment (Goretti and Souto 2013; Jaeger, 2003; Vermeulen 2000). Also Goretti and Souto (2003) use firm-level data by estimating the impact on the investment-to-capital ratio from debt overhang proxied by debtto-equity and interest coverage ratio, and find that their debt overhang has a negative impact on a firm's investment-to-capital.

The panel regression also suggests that a reduction in debt-to-equity could contribute to improvement in capital productivity ${ }^{4}$. Debt-to-equity has a negative and statistically significant coefficient on capital productivity (panel 3, panel 4). Literature also discusses corporate restructuring and productivity growth, where Abramovsky and Rachel Griffith

\footnotetext{
${ }^{4}$ See Appendix I for the definition of capital productivity.
} 
(2009) find that stronger productivity growth could be followed by business reorganization, and $\mathrm{Li}$ (2011) finds that the effects of restructuring is driven by improvements in a firm's productivity growth.

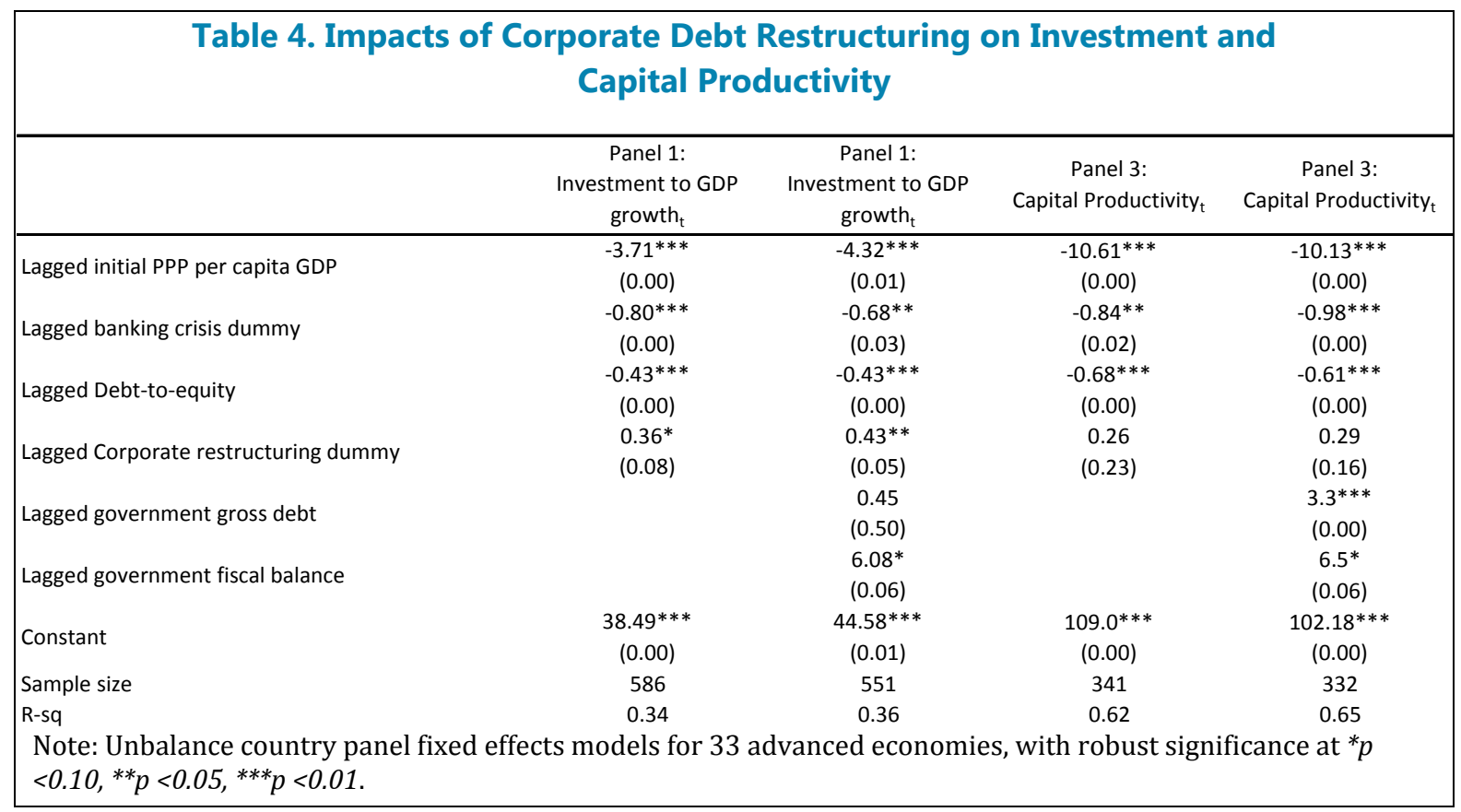

\section{Conclusion}

Corporates in Korea have been facing significant challenges due to sluggish global trade and rising competition from emerging markets, particularly China. While Korean corporates overall appear relatively healthy, some corporates appear to require restructuring. The authorities and corporates alike have stepped up efforts to restructure debt distressed firms in multi-pronged ways. Corporate restructuring is a daunting task, however, given its substantial uncertainty arising from the business outlook, and its impact on employment and business lines.

Corporate restructuring experience in other countries highlights the importance of financial supervisors and government policy; bank' soundness; market infrastructure; and the dimension of firm structuring. Specific lessons include: swift, timely restructuring where the financial supervisory authorities should play an important role to encourage banks to carry out credit restructuring; capital adequacy of banks and the appropriate role of the government to facilitate restructuring; clear guidelines that facilitate a collective process for workouts extended to non-financial creditors; an appropriate regulatory framework for spin-in and M\&A activity; market infrastructure to promote corporate restructuring during normal times; and firm-level financial and operational restructuring in multi-pronged ways.

This paper estimates the effects of corporate restructuring on macro variables, including real GDP growth, employment, investment, and productivity. This paper finds that both corporate debt restructuring and M\&A activity have a positive effect on real GDP growth with 
time lags. The paper also finds that debt restructuring could have a positive effect on growth in the medium-term either through increased investment or capital productivity. Corporate restructuring, however, could have a negative effect on the labor markets and the financial markets in the short term. These results may suggest the importance of setting policy to strengthen banking supervision and fiscal supports during a restructuring period to mitigate the potential negative spillovers on the banking sector and employment. 


\section{Appendix 1. Description of Data}

\begin{tabular}{|c|c|c|}
\hline Variables & Definition & Sources \\
\hline Real per capita GDP & Constant GDP/total population & IMF WEO (January 2016) \\
\hline purchasing-power-parity per Capita GDP & GDP in PPP dollars/total population & IMF WEO (January 2016) \\
\hline Capital productivity & $\begin{array}{l}\text { the ratio between the volume of output (GDP), and the volume of } \\
\text { capital input, defined as the flow of productive services that capital } \\
\text { delivers in production, i.e. capital services. }\end{array}$ & $\begin{array}{l}\text { OECD Compendium of } \\
\text { Productivity Indicators (2016) }\end{array}$ \\
\hline Unemployment rates & $\begin{array}{l}\text { The number of unemployed persons as a percentage of the labor } \\
\text { force }\end{array}$ & IMF WEO (January 2016) \\
\hline Aggregate corporate debt-to-equity & Debt/equity & Worldscope \\
\hline$M \& A / G D P$ & the total amount of mergers and acquisition/nominal GDP & Dealogic \\
\hline Banking crisis dummy & $\begin{array}{l}\text { Significant signs of financial distress in the banking system definded } \\
\text { by Laeven and Valencia (2008) }\end{array}$ & Laeven and Valencia (2008) \\
\hline Financial institutions depth & $\begin{array}{l}\text { Consisted of private sector credit to GDP, pension fund assets to } \\
\text { GDP, mutual fund assets to GDP, insurance premiums to GDP }\end{array}$ & Svirydzenka (2016) \\
\hline Fiscal balance (percent of GDP) & (Expenditure-Revenue)/nominal GDP & IMF WEO (January 2016) \\
\hline Government debt (percent of GDP) & $\begin{array}{l}\text { Gross debt consists of all liabilities that require payment or } \\
\text { payments of interest and/or principal by the debtor to the creditor } \\
\text { at a date or dates in the future. Gross debt is divided by nominal } \\
\text { GDP }\end{array}$ & IMF WEO (January 2016) \\
\hline
\end{tabular}




\section{Appendix 2. Country List}

The sample of countries is dictated by the availability of data in each panel.

\begin{tabular}{ll}
\hline Country & Country \\
\hline Australia & Latvia \\
Austria & Lithuania \\
Belgium & Luxembourg \\
Canada & Netherlands \\
Cyprus & New Zealand \\
Czech Republic & Norway \\
Denmark & Portugal \\
Finland & Puerto Rico \\
France & Singapore \\
Germany & Slovak Republic \\
Greece & Slovenia \\
Hong Kong SAR & Spain \\
Iceland & Sweden \\
Ireland & Switzerland \\
Israel & Taiwan Province of China \\
Italy & United Kingdom \\
Japan & United States \\
Korea & \\
\hline
\end{tabular}




\section{References}

Abramovsky, Laura, and Rachel Griffith, 2009, ICT, Corporate Restructuring and Productivity (Institute for Fiscal Studies).

Blazy, Regis, Jocelyn Martel, and Nirjhar Nigam, 2014, "The Choice between Informal and Formal Restructuring: The Case of French Banks Facing Distress SMEs."

Bernanke, Ben, Mark Gertler, and Simon Gilchrist, 1999 "The Financial Accelerator in a Quantitative Business Cycle Framework," in Handbook of Macroeconomics, Vol. I.

Borisova, Ginka, Veljo Fotak, Kateryna Holland, William L. Megginson, 2015, Government Ownership and the Cost of Debt: Evidence from Government Investments in Publicly Traded Firms, Journal of Financial Economics, pp. 169-191.

Caballero, Ricardo, Takeo Hoshi, and Anil Kashyap, 2008, “Zombie Lending and Depressed Restructuring in Japan," American Economic Review.

Cho, Hangrae, and Sangjin Park, 2013, "Giupgojojochung jedo hyunhyung mit gaesun banghyang,” Woori Finance Research Institute.

Choi, Yoon K., and Seung Hun Han, 2013, "Corporate Restructuring, Financial Deregulation, and Firm Value: Evidence from Japanese 'spin-ins'” Pacific-Basin Finance Journal 22, pp. 1-13.

Coricelli, Fabrizio, Nigel Driffield, Sarmistha Pal, and Isabelle Roland, 2010, "Excess Leverage and Productivity Growth in Emerging Economies: Is There a Threshold Effect?" Institute for the Study of Labor, (March).

Crum, Roy L and Itzhak Goldberg, 1998, Restructuring and Managing the Enterprise in Transition (Washington: World Bank).

Daley, Lane, Vikas MehrotraCOR, Ranjini Sivakumar, August 1997, "Corporate Focus and Value Creation Evidence from Spinoffs" Journal of Financial Economics, Vol. 45, No. 2.

Eagle, Ryan, 2014, "Restructuring in the Shipping Industry” Ferrier Hodgson, August.

Earle, John, Saul Estrin, and Larisa Leshchenko, 1996, “Ownership Structures, Patterns of Control, and Enterprise Behavior in Russia” (Washington: World Bank).

Grigorian, David A. and Faezeh Raei, 2010, "Government Involvement in Corporate Debt Restructuring: Case Studies from the Great Recession," IMF Working Paper 10/260 (Washington: International Monetary Fund). 
Goretti, Manuela, and Macros Souto, 2013, "Macro-Financial Implications of Corporate (De)Leveraging in the Euro Area Periphery," IMF Working Paper 13/154 (Washington: International Monetary Fund).

Hoshi, Takeo, Satoshi Koibuchi, and Ulrike Schaede, 2009, "Changes in Corporate Restructuring Processes in Japan, 1981-2008."

Huang, Jiang-Chuan, and Chin-Sheng Huang, 2011, "The Effects of Bank Relationships on Firm Private Debt Restructuring: Evidence from an Emerging Market," Research in International Business and Finance.

Inoue, Kotaro, Hideaki K. Kato, and Marc Bremer, 2008, "Corporate Restructuring in Japan: Who Monitors the Monitor?" Journal of Banking \& Finance.

Jaeger, Albert, 2003, Corporate Balance Sheet Restructuring and Investment in the Euro Area, IMF Working Paper 03/117 (Washington: International Monetary Fund).

Johnson, W. Gordon, 2005, "Developing an Effective Framework for Insolvency and Credit Rights," Corporate restructuring: lessons from experience Chapter 15, The World Bank.

Kam, Amy, David Citron, and Gulner Murandoglu, 2008, Distress and Restructuring in China: Does Ownership Matter? China Economic Review 19, pp. 587-579.

Kim, Se-Jik, 2003, Macro Effects of Corporate Restructuring in Japan, IMF Working Paper No 03/203 (Washington: International Monetary Fund).

Korea Institute of Finance and Ehwa Women's University Bankruptcy Law Center, 2014, "Giupgujojochungchokjinbup Sangsibupjeihwa bangan."

Kumar, Manmohan S. and Jaejoon Woo, 2010, "Public Debt and Growth," IMF Working Paper No. 10/174 (Washington: International Monetary Fund).

Laeven, Luc and Fabian Valencia, 2008, "Systemic Banking Crises: A New Database," IMF Working Paper No. 08/224 (Washington: International Monetary Fund).

Laeven, Luc, and Fabian Valencia, 2012, Systemic Banking Crises Database: An Update, IMF Working Paper 12/163 (Washington: International Monetary Fund).

Laryea, Thomas, 2010, "Approaches to Corporate Debt Restructuring in the Wake of Financial Crises," IMF Staff Position Note SPN/10/02 (Washington: International Monetary Fund).

Li, Xiaoyang, 2011, "Productivity, Restructuring, and the Gains from Takeovers" (Detroit: University of Michigan). 
Montes-Negret, F. and L. Papi, 1997, "The Polish Experience with Bank and Enterprise Restructuring,” Policy Research Working Paper No. 1705 (Washington: World Bank).

Pomerleano, Michael and William Shaw, 2005, "Corporate Restructuring: Lessons from Experience" (Washington: World Bank).

Smart, Scott B, and Joel Waldfogel, 1994, "Measuring the Effect of Restructuring on Corporate Performance: The Case of Management Buyouts," Review of Economics and Statistics.

Stone, Mark R., 2002, Corporate Sector Restructuring: The Role of Government in Times of Crisis, IMF Economic Issues No. 31 (Washington: International Monetary Fund).

Svirydzenka, Katsiaryna, 2016, "Introducing a New Broad-based Index of Financial Developments," IMF Working Paper No. 16/5 (Washington: International Monetary Fund).

The Korean Government, 2016, "Sanup, Giup Gujojojung chujingyeheok mit gukchaekeunhang jabonwhakchung dung bowanbangan,” (June).

Woo, Jaejoon and Manmohan S. Kumar, 2015, "Public Debt and Growth," Economica.

Vyas, Krishna Kant, 1997, “Corporate Restructuring and Value Creation,” University of Groningen. Chapter 4. 